\section{EREM 76/4}

Journal of Environmental Research, Engineering and Management

Vol. 76 / No. 4 / 2020

pp. 46-59

DOI 10.5755/j01.erem.76.4.27369
Towards Zero Solid Waste in Jordanian Universities: The Case of AlAhliyya Amman University
Accepted after revision 2020/11

\title{
Towards Zero Solid Waste in Jordanian Universities: The Case of Al-Ahliyya Amman University
}

\author{
Zahra Al-Shatnawi*, Saba Alnusairat, Anan Kakani
}

Department of Architecture Engineering, Faculty of Architecture and Design, Al-Ahliyya Amman University, Amman, Jordan, Postal address: (19328)

*Corresponding author: z.shatnawi@ammanu.edu.jo / zahraa_shatnawi@hotmail.com

This paper investigates solid-waste management performance potential within Al-Ahliyya Amman University (AAU), Jordan, in the context of environmental benefits and the UI green metric rating system waste category indicators. First, a field survey was conducted to characterise and quantify solid waste generated in AAU. Second, a checklist of the solid-waste management practices in university campuses was developed, based on the UI green metric rating system. Finally, the environmental impact of implementing solid-waste management in AAU campus was measured using the zero waste index (ZWI). The findings show that 491 tonnes of mixed waste are produced each year on campus, of which compostable waste, recyclables, and non-recyclables account for around $21 \%, 47 \%$, and $32 \%$, respectively. Using the ZWI to measure the performance of waste management practices, the study found a score of 0.75 for non-recyclable paper and plastic prevention; paper, plastic, and metal recycling; and organic composting. Paper recycling was found to have the greatest impact on virgin material substitution, and metal recycling has the highest potential for energy, water, and greenhouse-gas savings. Waste management projects in Jordanian universities should include reduction, in addition to paper and metal recycling in phase 1; and plastic recycling and composting should be applied in phase 2 . Since not all waste management practices have the same environmental impact, the study recommends redistributing the UI green metric waste indicators points in accordance with environmental impact.

Keywords: Solid waste management, higher educational institutes, zero waste, UI green metric, Jordan. 


\section{Introduction}

Waste management is a vital issue that affects the society and economy of any urban settlement. It has strong connections to global issues of health, climate change, poverty reduction, food and resource security, and sustainable production and consumption (UNEP, 2015). Each year, in Jordan, millions of metric tonnes of solid waste are generated from municipal, industrial, and agricultural sources. The growing industrialisation and the high population-growth rate are the main drivers of the increasing amounts of waste. The Jordanian solid-waste management sector is one of the most complex sectors in the country, due to the wide variety of solid waste types and compositions. In 2015, the average waste generation rate in Jordan was $0.99 \mathrm{~kg} / \mathrm{cap} /$ day in urban areas and $0.87 \mathrm{~kg} / \mathrm{cap} /$ day in rural areas. Most solid waste in Jordan ends up in one of the 18 official operating disposal sites (JGBC, 2016). The Ministry of Municipals Affair (MoMA) in Jordan is in charge of the regulations and management of non-hazardous waste, including municipal solid waste (JICA, 2017). One of the findings of the Japan International Cooperation Agency (JICA) surveys is that the central and local government authorities lack the financial ability to supply public organisations - named 'Joint Service Councils' - with the necessary equipment, and the waste management sector is not a top priority in the central government budget share. Furthermore, the low level of knowledge and awareness of the environmental and health impacts of improper management of solid waste complicates the implementation of disposal and recycling programmes (Mrayyan and Hamdi, 2006). The national Green Growth Plan, published by Jordan's Ministry of Environment, established a target to reduce waste sent to landfill from 80\% in 2017 to 60\% in 2025 (Ministry of Environment, 2017).

Several authors who demonstrated the significance of sustainability in university campuses (Alshuwaikhat and Abubakar, 2008; Parvez and Agrawal, 2019) believe that higher education institute campuses represent a city's urban characteristics on the micro-level, as they produce similar environmental impacts. Hence, they can be considered small cities. As a result, university campuses can impact the city and influence local neighbourhoods to adopt and implement sustainable practices. Baily (2015) argued that higher educational institutes can play a major role in promoting sustainable development due to inherent expertise among university staff and students as well as their engagements with the wider community.

Fig. 1. Jordanian universities' performance in the UI green metric waste category (UI Green Metric, 2019)

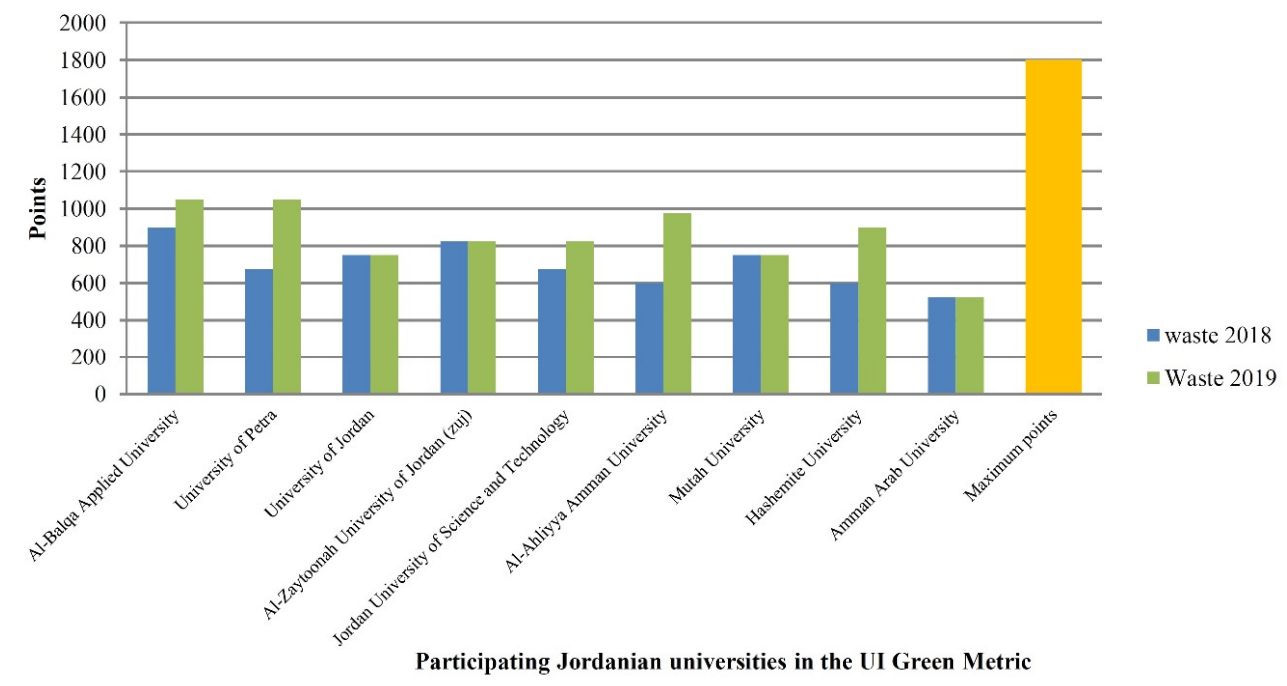


There have been many efforts to apply the concept of sustainability to higher educational institutions. One of the initiatives is the $\mathrm{Ul}$ green metric rating system, which measures the sustainability efforts within university campuses in six main categories: setting and infrastructure, energy and climate change, waste, water, transportation, and education, with a potential of 10,000 points that can be scored. In 2019, 780 universities from 83 countries participated in the ranking (UI Green Metric, 2019), and in Jordan specifically, 9 universities out of 34 private and public universities participated (UI Green Metric, 2019; Ministry of Higher Education and Scientific Research, 2017).

The performance of Jordanian universities in the waste category is the weakest compared with the other categories, as the average achieved score in 2018 and 2019 was $43 \%$ of the maximum achievable score. Moreover, most universities showed no to minimum improvement in their scores over the two-year period (Fig. 1).

The waste category in the UI green metric system is divided into six indicators, each weighing 300 points. Four of these indicators are dedicated to solid waste (programmes to reduce paper and plastic on campus, recycling programmes, organic-waste treatment, and inorganic-waste treatment). The system gives a general score out of 1800 , without specific scores for each indicator (UI Green Metric, 2019). As a result, it can be challenging to identify the weak areas in this category for university campuses.

The importance of this study is well noted by Smyth et al. (2010), who observe that comprehensive solid-waste management programmes are one of the greatest challenges for achieving campus sustainability. Important indicators for waste management and the environmental impact of different waste-management systems have not been previously investigated in Jordanian universities. Therefore, this paper explores solid-waste management performance potential within AAU in the context of environmental benefits, taking the UI green metric waste category indicators into consideration.

\section{Case Description}

Al-Ahliyya Amman University (AAU) has one campus, covering a total land area of $185,109 \mathrm{~m}^{2}$. It is located in a suburban setting between the capital Amman and the city of Al-Salt, with a Mediterranean climate. The campus consists of 21 permanent buildings (including academic activities facilities, female student dormitories, and services) and nine temporary structures (including caravans, kiosks, and shelters). The main campus building footprint is $2,2476 \mathrm{~m}^{2}$. The buildings and structures account for $95,068 \mathrm{~m}^{2}$ of the total area. A total of 7,179 students enrolled in the first semester of the academic year 2019/2020. There were 646 university staff in the same year (326 academic and 321 administrative; AAU, 2019).

This study was conducted during the first semester of the academic year 2019/2020. The university's dormitories were excluded from the scope of this research due to the sensitivity and privacy of this part of campus, which is reserved solely for women.

\section{Methods}

\section{Field survey}

\section{Waste characterisation}

A full understanding of the composition of solid waste is vital for informing management (Denison and Ruston, 1990). A widely accepted approach to waste characterisation is direct waste analysis (DWA), also referred to as the 'sample and sort' method. Following this approach, waste samples are sorted, typically by hand, into previously selected material categories and weighed (Yu and Maclaren, 1995). Waste sampling can be conducted at the disposal facility (e.g., landfill) or directly from generators (e.g., dumpsters and curb-side set-outs) (SENES, 1999). As dormitories were excluded from this study, the generator-based sampling design was more suitable because it can provide much higher precision than disposal facility sampling designs when there is variation between sectors or precise estimates are required from a specific sector (SENES, 1999).

Research by Klee et al. (1970) and Britton (1972) suggests that the optimal weight for sampling is between 90 and $135 \mathrm{~kg}$ for municipal solid waste. In this study, each sorting sample weighed $100 \mathrm{~kg}$, as this is a good representative of the total waste characteristics (ASTM, 2016). The samples were collected from six waste generating 
locations. Each location included 2-3 containers, and each sample was prepared properly (mixed, coned, and quartered) according to the EPA (1996) procedure. Waste composition categories were based on the waste-management guide issued by JGBC (2016), as this was the only specialised source in Jordan (Table
1). Based on the given categories, arrangements were made with the university's cleaning company and a training session was conducted for seven workers of the company to explain how to collect, sort, and weigh the waste using a mechanical weighing scale, under the research team's supervision.

Table 1. Waste composition categories in Jordan (JGBC, 2016)

\begin{tabular}{l|l}
\multicolumn{1}{c|}{ Type of waste } & \multicolumn{1}{c}{ Description } \\
\hline Organic waste & $\begin{array}{l}\text { Fruits, vegetable residues, spoilt foodstuffs, leftovers, coffee grinds, tealeaves, egg shells, garden } \\
\text { waste, grass cuttings, dead leaves }\end{array}$ \\
\hline Recyclable metal & Aluminium cans (soda pop cans), scrap metal, tin cans \\
\hline Non-recyclable metal & Bottle and jar lids with plastic liners, cans used for chemicals or paint, aerosol spray cans \\
\hline Recyclable paper and & $\begin{array}{l}\text { Newsprint, office paper, computer paper, phone books, paper grocery bags, paper egg cartons, } \\
\text { corrugated (packing boxes), single-wall cartons (cereal boxes) }\end{array}$ \\
\hline Non-recyclable paper and & $\begin{array}{l}\text { Soiled paper, wax or plastic-coated paper, paper laminated with foil or plastic, used paper } \\
\text { towels, napkins, tissues, plates, magazines, catalogues, waxed cardboard, waxed milk cartons }\end{array}$ \\
\hline Cloth: synthetic textile & Cotton or any type of cloth \\
\hline Recyclable plastic & $\begin{array}{l}\text { Type 1: polyethylene terephthalate; type 2: high density polyethylene; type 4: low-density } \\
\text { polyethylene; type 5: polypropylene; type 7: other }\end{array}$ \\
\hline Non-recyclable plastic & Type 3: vinyl; type 6: polystyrene \\
\hline Recyclable glass & Jars, bottles (clear, green, brown) \\
\hline Non-recyclable glass & Light bulbs, glassware (cups, glasses, plates, etc.), mirrors \\
\hline E-waste & PCs, white goods, batteries, CRTS, flat screens \\
\hline Wood and yard waste & Wood, doors, window frames roof tiles, building debris \\
\hline Other & Any other type \\
\hline
\end{tabular}

The weight of each waste subcategory in the samples was recorded in a database. The weight percentage for each subcategory was calculated using the following equation:

$P_{S}=\frac{P_{L}}{P_{T}} * 100$

Where: $P_{s}$ - the sub-category percentage; $P_{L}:-$ the amount of the sub-category in $\mathrm{kg} ; P_{T}$ - total weight of sample in $\mathrm{kg}$.

For this research, the waste collection, sorting, and weighing were conducted during week 8 of the first academic semester $(2019 / 2020)$, and the collection was made between 9 am and $2 \mathrm{pm}$. All samples were taken on working days to ensure that the results represented the normal university operations during an academic year.

\section{Waste quantification}

In the field study, data were collected on current solid-waste management (MSW) at AAU and daily solid-waste generation on campus, through (a) interviews from professionals in AAU's supporting services department and (b) recorded documents from the campus authorities.

The estimation of the waste component generation rate, based on the percentage of the component and the per-capita waste generation rate/coefficient, was calculated using the following equation:

$G_{T}=G_{R} * P_{S} * M * 10^{-3} * N$

(based on Eyinda and Aganda, 2013)

Where: $G_{T}$ - generation of MSW component of the city/ town/municipality (ton/year); $G_{R}-$ MSW generation 
coefficient $\left(\mathrm{kg} /\right.$ person $/$ day); $P_{s}$ - percentage of waste component; $M$ - population of the city/town/municipality; $N$ - number of days.

MS Excel-based linked templates were used. These are designed to systematise the data entry and automatically generate estimates and data summaries.

Ul green metric solid-waste management applications

The three highest-ranked universities in the $\mathrm{UI}$ green metric (2019) waste category were analysed in terms of their solid-waste management practices (Table 4). These were UC Davis, Glasgow Caledonian University, and Wageningen UR University \& Research Center. The information available on the website of these universities regarding their solid-waste management programmes and policies was reviewed. These universities have established the goal of achieving zero waste; thus, a checklist of their campus waste-management practices was developed to provide strategic recommendations for future waste-management policies and programmes at AAU, with regards to the UI green metric waste indicators.

\section{Zero-waste index (ZWI)}

Zero waste practices involve 'designing and managing products and processes to systematically avoid and eliminate the volume and toxicity of waste and materials, conserve and recover all resources, and not burn or bury them' (ZWAl, 2009).

A widely used performance assessment method for waste management is the waste-diversion rate. This rate can be defined as the percentage of total waste that is diverted from disposal at landfills and from incineration at transformation facilities. The waste is directed to waste-management programmes such as reduction, reuse, recycling, and composting (CalRecycle, 2012). According to Marpman (2011), this method is not effective for zero-waste initiatives, as it does not give the whole picture of recycling initiatives and does not indicate how much of the waste stream is recyclable, whether all recyclables are being recycled, and how much less waste is being generated overall.

This study applied the zero-waste index (ZWI) developed by Zaman and Lehmann (2013) to measure the

Table 2. Substitution factor in different waste streams and management options for the zero-waste index (Zaman and Lehmann, 2013)

\begin{tabular}{l|c|c|c|c|c}
\hline $\begin{array}{c}\text { Waste management } \\
\text { systems }\end{array}$ & $\begin{array}{c}\text { Waste } \\
\text { category }\end{array}$ & $\begin{array}{c}\text { Virgin material } \\
\text { substitution } \\
\text { efficiency } \\
\text { (tonnes) }\end{array}$ & $\begin{array}{c}\text { Energy substitution } \\
\text { efficiency } \\
\text { (GJLHV/tonne) }\end{array}$ & $\begin{array}{c}\text { Global green- } \\
\text { house-gas } \\
\text { emissions reduction } \\
\text { (CO2e/tonne) }\end{array}$ & $\begin{array}{c}\text { Water saving } \\
\text { (kL/tonne) }\end{array}$ \\
\cline { 2 - 6 } & Paper & $0.84-1.00$ & $6.33-10.76$ & $0.60-3.20$ & 2.91 \\
\cline { 2 - 6 } Recycling & Glass & $0.90-0.99$ & $6.07-6.85$ & $0.18-0.62$ & 2.30 \\
\hline & Metal & $0.79-0.96$ & $36.09-191.42$ & $1.40-17.8$ & $5.97-181.77$ \\
\hline Clastic & $0.90-0.97$ & $38.81-64.08$ & $0.95-1.88$ & -11.37 \\
\hline Incineration & Mixed & $0.25-0.45$ & $5.00-15.0$ & 1.15 & $2.0-10$ \\
\hline Landfill & Organic & $0.60-0.65$ & $0.18-0.47$ & $0.25-0.75$ & 0.44 \\
\hline
\end{tabular}

environmental benefits of waste-management strategies, with an AAU waste characterisation and quantification field survey. The ZWI measures the potential of virgin materials to be offset by waste management systems, thereby saving energy and limiting global greenhouse gas (GHG) emissions and water consumption.
The $\mathrm{ZWI}$ is a powerful tool for comparing different waste management systems and giving a broader picture of their potential environmental impact. The $Z W I$ is calculated using equation (3). The material substitution efficiency is calculated using the material substation factor (Table 2). 
Zero-waste index $(\mathrm{ZWI})=\frac{\sum \text { potential amount of waste managed by the university } * \text { substitution for the systems }}{\text { Total amount of waste generated by the university }}$

Zero-waste index $(Z W I)=\frac{\sum_{i-1}^{n}(W M S i j * S F i j)}{\sum_{1}^{n} G W S}($ Zaman an Lehmann, 2013)

Where: WMSij - of waste streams $i$ ( $i=$ type of waste) managed by different systems $j$ ( $j=$ waste management system); SFij - substitution factor for different waste streams ( $i$ = type of waste) for different management systems ( $\mathrm{j}$ = waste management system), based on their virgin material replacement efficiency; GWS - amount of waste generated ( $\mathrm{i}=1$ to $\mathrm{n}$, all waste streams).

The ZWI was used in a previous study to compare the waste-management performances of different cities (Zaman and Lehmann, 2013). The study found that the ZWI could provide a more accurate and precise analysis of environmental benefits in the presence of high-quality data. Hence, the field study was conducted to produce accurate numbers regarding waste characterisation and quantification in AAU. It is also evident from previous studies (Zman and Lehman, 2013; Zman, 2014) that the $\mathrm{ZWI}$ can be used for a local or global scale.

\section{Results and Discussion}

\section{Solid-waste characterisation and quantification at Al-Ahliyya Amman University}

A total of 30 samples was collected and sorted. After the samples had been weighed and equation (1) applied, the results showed that the major components in the general waste stream were paper and cardboard, organic waste, plastic, and recyclable metal. This study revealed that $21 \%$ of campus waste had the potential to be composed. Moreover, $47 \%$ of waste can be recycled (Fig. 2). The authors acknowledge that a longer monitoring duration would have produced more samples and, therefore, more data on consumption patterns.

Considering the waste composition categories in Jordan (Table 1), recyclable and non-recyclable paper and cardboard have the most impact, comprising 26\% and $25 \%$ of the total waste, respectively. Waxed cardboard in the form of plates, hot beverage cups, and food containers is a major contributor to non-recyclable paper and cardboard waste. In addition, organic material - including food and garden waste - accounts for $21 \%$ of the waste stream. Recyclable plastic was found primarily in the form of type 1 plastic, with water and soda bottles being the major components. Non-recyclable plastic consisted primarily of types 3 and 6 , with clear food packaging and cups and plates comprising the majority of the waste stream. Another component was recyclable metal, which consisted largely of aluminium cans. This type accounted for $12 \%$ of the total waste stream due to its weight (Fig. 2). All this indicates that food and drink waste make up a large proportion of the university campus total.

In $A A U$, light bulbs and e-waste (including batteries and computers) are not included in the single-stream general waste and are collected and treated separately. Therefore, they were not found in the general waste samples when conducting the survey.

According to Wagner and Bilitewski (2009) and Ghose et al. (2006), waste content percentages differ from place to place, and this has been demonstrated in several studies. In the Smyth et al.'s (2010) study of the Prince George campus of the University of Northern British Columbia (UNBC) in Canada, recyclable materials made up around $37 \%$ of waste in most activity areas and compostable materials around 19\%. The non-recyclable matter was made up of residual plastic (primarily packaging) and composite materials. De Vega et al. (2008), in their study of Mexicali I of the Autonomous University of Baja California (UABC), Mexico, found that a large proportion of the waste generated on campus could be recycled or composted. Of the total waste generated in buildings, the paper and cardboard category represents the largest percentage (33.02\%) of recyclable waste. In the case of waste from gardens, compostable material comprises the majority (80.12\%). The same applies in 
the case of waste from the community centre (53.72\%). The Starovoytova (2018) study of the Moi University in Kenya revealed that compostable waste and recyclable waste accounted for $37 \%$ and $62 \%$ of the total waste on campus, respectively. Mixed paper was the largest contributor to recyclable content (28\%), followed by glass (13\%). Mokbel (2018), in a study at the University of Jordan, concludes that recyclable and compostable waste accounted for $64 \%$ and $25 \%$ of the total, respectively. Paper and cardboard waste - excluding hot beverage cups - accounted for the highest percentage of waste.

Although the percentages of the waste components differ between one campus and another, the studies cited above show that paper and cardboard and compostable waste are the greatest contributors to the waste stream. Plastic also has a dominant presence. This corresponds with the findings of this study.

Fig. 2. Waste composition percentages according to recycling potential, and the waste composition average in Al-Ahliyya Amman University

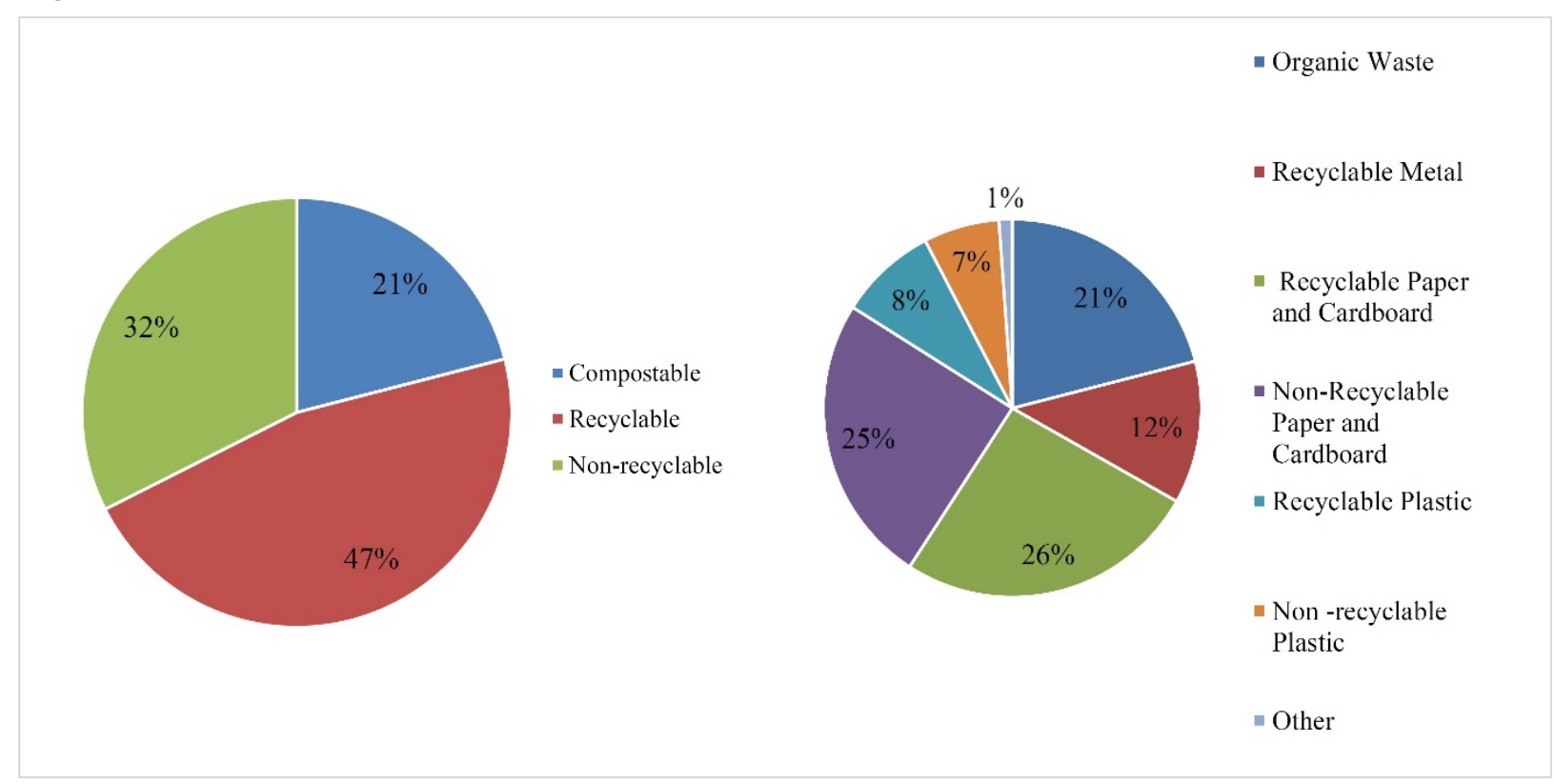

Following focus group interviews and the collection of documents from the campus authorities, it was estimated that around $5,000 \mathrm{~kg}$ of solid waste was produced each day on campus. Data for the average numbers of students and staff members in an academic year were also collected. By dividing the total waste generated each day by the average number of students and staff members in an academic year, the solid waste generation coefficient was found to range between 0.64 and $0.77 \mathrm{~kg} /$ capita/day, with a mean of $0.70 \mathrm{~kg} / \mathrm{capita} /$ day. The generation of total waste component per year was calculated using equation (2), and the results are presented in Table 3. The number of days is based on the university's calendar, as each regular academic semester and summer semester consist of 15 weeks and 8 weeks, respectively. An academic week consists of five days.
The study shows that the university campus generates an average of 491 tonnes of mixed waste per year, of which (i) compostable waste accounts for around 104 tonnes, (ii) recyclables account for around 228 tonnes, and (iii) non-recyclables account for around 159 tonnes.

De Vega et al. (2008) found that the solid-waste generation rate in the UABC Mexicali I Campus was an average of 1 tonne/day. Starovoytova (2018) estimated that the university campus generated an average of $5,111.65$ tonnes of mixed waste per year, at a rate of $0.5 \mathrm{~kg} / \mathrm{cap}$ ita/day, and Mokbel (2018) found that waste generated from the university campus reached an average of 8,113 $\mathrm{kg} /$ day. The fluctuations in the amount of waste generated on campuses reflects the changing numbers of enrolled students, as well as the consumption patterns in each country. 
Table 3. Solid-waste generation at Al-Ahliyya Amman University

\begin{tabular}{|c|c|c|c|c|}
\hline $\begin{array}{l}\text { Average number } \\
\text { of students and }\end{array}$ & $\begin{array}{l}\text { Average number } \\
\text { of students and }\end{array}$ & \multicolumn{2}{|c|}{$\begin{array}{c}\text { Waste } \\
\text { component }\end{array}$} & \multirow{2}{*}{$\begin{array}{c}\text { Generation of solid-waste } \\
\text { management (MSW) waste } \\
\text { component (tonne/year) } \\
129\end{array}$} \\
\hline \multirow[t]{9}{*}{7,329} & 4,027 & \multirow{4}{*}{ Recyclable } & Paper & \\
\hline & & & Metal & 59.4 \\
\hline & & & Plastic & 39.5 \\
\hline & & & Mixed & - \\
\hline & & Compostable & Organic & 104.3 \\
\hline & & \multirow{3}{*}{ Non-recyclable } & Paper & 119.6 \\
\hline & & & Plastic & 34.6 \\
\hline & & & Other & 4.9 \\
\hline & & \multicolumn{2}{|c|}{ Total } & 491.3 \\
\hline
\end{tabular}

\section{UI green metric solid-waste management applications}

The waste-management policies and programmes for the three most highly ranked universities in the waste category of the UI green metric rating system were reviewed in accordance with the rating system indicators (Table 4). The four indicators for solid-waste management are programmes to reduce paper and plastic in campus, recycling programmes, organic waste treatment, and inorganic waste treatment. These indicators follow the waste management hierarchy. There are five identified actions to be developed in the waste management hierarchy, in order of priority and according to their significance for appropriate waste management. The five actions are (1) prevention, (2) re-use, (3) recycling, (4) other recovery, and (5) disposal (European Parliament and of the Council of the European Union, 2008).

Since waste prevention is at the top of the inverted pyramid of the waste hierarchy, different programmes that aim to reduce paper and plastic waste are implemented within the three universities. These programmes are low cost, such as introducing a charge for disposable cups and plates, as well as reducing paper documents by digitalising paperwork and double-side printing. The introduction of water fountains on the university campus is another strategy to reduce the purchase of water bottles. The authors of this research acknowledge that the UI green metric works on the waste-management system and not the production system to reduce solid waste, which does not comply fully with the concept of zero waste (Zaman, 2014; Schall, 1992; Price and Joseph, 2000). Reuse as a waste-management strategy is applied for books, computers, and furniture on these campuses, resulting in less waste being sent to landfill.

Recyclable waste is separated and collected on-site in these universities and recycled off-site at specialised facilities. Recyclables include paper and cardboard, plastic, metal, and glass. Moreover, electronic waste, batteries, and lamps are collected separately and either recycled or treated in a responsible manner.

Organic waste is treated by anaerobic digestion, at a facility on or off-campus, producing electricity or agricultural soil conditioner. Energy production from waste is the fourth priority in waste management, according to the waste hierarchy, and it generally applies to organic waste. These universities have zero-waste policies, minimising the quantity of waste sent to landfill. Nonetheless, Glasgow Caledonian University converts the remaining general waste to refuse-derived fuel. This does not correspond with the concept of zero waste (Connett, 2013; ZWAI, 2009), as zero-waste management restricts the application of waste-to-energy as a recovery strategy that burns waste to generate energy, resulting in GHG emissions. Therefore, some of these campuses do not maintain zero-waste 
principles in regards to their treatment of organic waste through anaerobic digestion and inorganic waste through conversion to refuse-derived fuel. Moreover, source reduction is not taken into consideration.

Table 4. High-ranked universities checklist for solid-waste management (UC Davis, Glasgow Caledonian University, Wageningen UR University \& Research Centre)

\begin{tabular}{|c|c|c|c|c|}
\hline \multicolumn{2}{|r|}{ Indicator } & \multirow{2}{*}{$\begin{array}{c}\text { Wageningen University } \\
\text { and Research } \\
\checkmark\end{array}$} & \multirow{2}{*}{$\begin{array}{c}\text { Glasgow Caledonian } \\
\text { University } \\
\checkmark\end{array}$} & \multirow{2}{*}{$\begin{array}{c}\text { University of California, } \\
\text { Davis } \\
\checkmark\end{array}$} \\
\hline \multirow{7}{*}{ 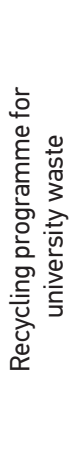 } & Paper and cardboard & & & \\
\hline & Plastic & $\checkmark$ & $\checkmark$ & $\checkmark$ \\
\hline & Metal & $\checkmark$ & $\checkmark$ & $\checkmark$ \\
\hline & Glass & $\checkmark$ & $\checkmark$ & $\checkmark$ \\
\hline & Electronic waste & $\checkmark$ & $\checkmark$ & $\checkmark$ \\
\hline & Lamps & $\checkmark$ & $\checkmark$ & $x$ \\
\hline & Batteries & $\checkmark$ & $\checkmark$ & $x$ \\
\hline \multirow{6}{*}{ 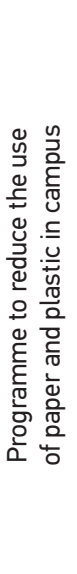 } & $\begin{array}{l}\text { Applying charge on disposable } \\
\text { cups and plates }\end{array}$ & $x$ & $\checkmark$ & $x$ \\
\hline & $\begin{array}{l}\text { Using environmentally friendly } \\
\text { cups and plates or packaging }\end{array}$ & $\checkmark$ & $x$ & $\checkmark$ \\
\hline & Using reusable dishware & $\checkmark$ & $\checkmark$ & $\checkmark$ \\
\hline & Digitalisation of paperwork & $\checkmark$ & $x$ & $\checkmark$ \\
\hline & Water fountains & $x$ & $\checkmark$ & $x$ \\
\hline & Double sided printing & $x$ & $x$ & $\checkmark$ \\
\hline \multirow{2}{*}{ 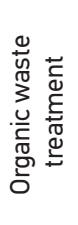 } & Composting & $\checkmark$ & $\checkmark$ & $\checkmark$ \\
\hline & Anaerobic digestion & $\checkmark$ & $\checkmark$ & $\checkmark$ \\
\hline \multirow{3}{*}{ 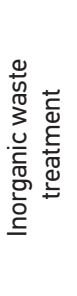 } & Lamps & $x$ & $x$ & $\checkmark$ \\
\hline & Batteries & $x$ & $x$ & $\checkmark$ \\
\hline & $\begin{array}{l}\text { General waste converted } \\
\text { refuse derived fuel }\end{array}$ & $x$ & $\checkmark$ & $x$ \\
\hline
\end{tabular}




\section{Environmental impact of zero-solid-waste management at Al-Ahliyya Amman University}

The application of equation (3) reveals that the ZWI for recycling and composting as waste-management strategies in AAU is 0.52 . This means that $52 \%$ of solid waste generated on campus can be recovered by implementing these strategies. Although waste prevention is a core component of the zero-waste concept, it has not been considered in previous studies (Zaman and Lehmann, 2013; Zaman et al., 2016).

The authors of this research acknowledge that waste prevention requires social awareness and knowledge of waste and innovative manufacturing and business models. Sustainable and responsible consumer behaviour is another important issue to consider in waste prevention. However, an indication of the potential impact was measured in this research by applying a strategy for non-recyclable paper and non-recyclable plastic. Accordingly, the amount of waste sent to landfill would decrease. Equation (3) reveals that the ZWI was 0.75; thus, $75 \%$ of solid waste generated on campus can be recovered by implementing non-recyclable paper and plastic prevention; paper, plastic, and metal recycling; and organic composting. This highlights the importance of source reduction as the first approach to waste management. The results also indicate that paper recycling in AAU has the highest potential for virgin material substitution, followed by organic composting (Fig. 3).

Table 5. Potential substitution of resources in the zero-waste index at Al-Ahliyya Amman University

\begin{tabular}{|c|c|c|c|c|c|c|c|}
\hline $\begin{array}{c}\text { Waste } \\
\text { management } \\
\text { systems }\end{array}$ & $\begin{array}{l}\text { Waste } \\
\text { category }\end{array}$ & $\begin{array}{l}\text { Total waste } \\
\text { in the univer- } \\
\text { sity (tonnes) } \\
\text { (iv) }\end{array}$ & $\begin{array}{l}\text { Potential total } \\
\text { virgin material } \\
\text { substituted (tonnes) } \\
\text { (v) }\end{array}$ & $\begin{array}{c}\text { Total energy } \\
\text { substituted } \\
\text { (GJLHV) }\end{array}$ & $\begin{array}{l}\text { Total GHG emis- } \\
\text { sions reduction } \\
\text { (tonnes } \mathrm{CO}_{2} \mathrm{e} \text { ) }\end{array}$ & $\begin{array}{l}\text { Total water } \\
\text { saving } \\
(\mathrm{kL})\end{array}$ & $\begin{array}{c}\text { Zero-waste } \\
\text { index, } \\
(\mathrm{WWI}=\mathrm{v} / \mathrm{iv})\end{array}$ \\
\hline \multicolumn{8}{|c|}{ Waste prevention not implemented } \\
\hline \multirow{3}{*}{ Recycling } & Paper & 129 & 108 & 1,102 & 245 & 375 & \multirow{6}{*}{0.52} \\
\hline & Metal & 59 & 47 & 6,757 & 566 & 5538 & \\
\hline & Plastic & 40 & 36 & 2,032 & 57 & -455 & \\
\hline Composting & Organic & 104 & 62 & 34 & 52 & 46 & \\
\hline Landfill & Mixed MWa & 159 & 0 & 0 & -67 & 0 & \\
\hline \multicolumn{2}{|c|}{ Total value } & 491 & 253 & 9,925 & 853 & 5,504 & \\
\hline \multicolumn{8}{|c|}{ Waste prevention implemented } \\
\hline \multirow{3}{*}{ Recycling } & Paper & 129 & 108 & 1,102 & 245 & 375 & \multirow{6}{*}{0.75} \\
\hline & Metal & 59 & 47 & 6,757 & 566 & 5538 & \\
\hline & Plastic & 40 & 36 & 2,032 & 57 & -455 & \\
\hline Composting & Organic & 104 & 62 & 34 & 52 & 46 & \\
\hline Landfill & Mixed MWa & 5 & 0 & 0 & -2.1 & 0 & \\
\hline \multicolumn{2}{|c|}{ Total value } & 337 & 253 & 9,925 & 918 & 5,504 & \\
\hline
\end{tabular}

Energy, water, and waste are considered priority sectors in the National Green Growth Plan of Jordan. The country's energy sector is traditionally known for its relatively high fossil fuel energy mix, compared with many neighbouring countries. Moreover, Jordan has historically been dependant on GHG-intensive, imported fossil fuel sources for energy. The total emissions from the energy sector alone have constituted $72.9 \%$ of Jordan's total GHG emissions. The water sector presents a crucial challenge to the country, as Jordan has one of the lowest levels of 
water availability per capita in the world, with less than $145 \mathrm{~m}^{3}$ (Ministry of Environment, 2017). Energy and water are important resources associated with waste. Potential waste-management systems in AAU can substitute the energy demand of 9,925 gigajoules (GJ), and total water savings can reach 5,504 kilolitres (Table 5). It is evident that, on campus, metal recycling has the largest impact on energy and water savings (Fig. 3). This finding is supported by the study of Chapman and Roberts (1983), which indicates that aluminium from ore uses approximately 20 times more energy than recycled metal. Plastic recycling follows metal recycling in energy substitution at AAU, and paper recycling takes the second place in water savings, after metal recycling. It is also noted that plastic recycling consumes water (Fig. 3).

Landfill disposal is an important contributor to anthropogenic climate change, accounting for approximately 5\% of GHG emissions (Stocker, 2013). Reducing GHG emissions in Jordan aligns with the national priority of reducing reliance on imported fossil fuels (Ministry of
Environment, 2017). The reduction in GHG emissions if waste management were applied in AAU is estimated at around 918 tonnes of CO2e (Table 5). In AAU, metal recycling has the highest potential for $\mathrm{GHG}$ reduction, followed by paper recycling (Fig. 3). Although landfill disposal is the lowest priority in the waste hierarchy and should not be considered in a zero-waste management plan, several factors contribute to the consideration of landfill as the only practical environmental option in developing countries. These are availability of space, lack of technology, limited financial tools for developing selective collection systems, and low disposal costs (UNDP, 2015). The findings of this study indicate that if the appropriate waste management strategies were applied on the AAU campus, landfill waste could reach 5 tonnes/year, compared with the current 491 tonnes/year (Table 5).

The UI green metric waste category gives a total of 1,200 points for solid-waste management indicators, with points distributed equally between these indicators. The results of this study indicate that solid-waste

Fig. 3. Environmental impact for potential waste-management systems in Al-Ahliyya Amman University

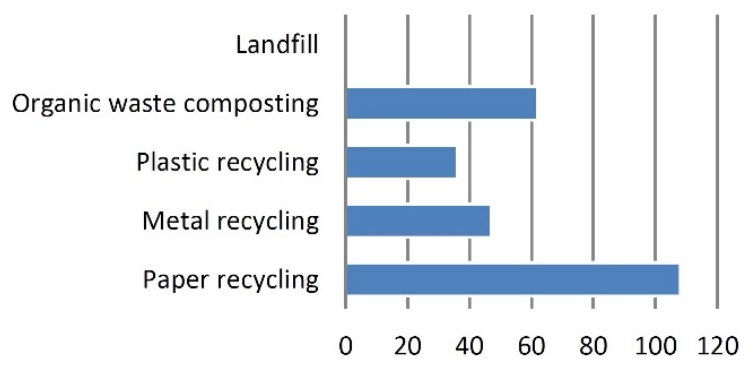

- Potential total virgin material substituted (tonnes)

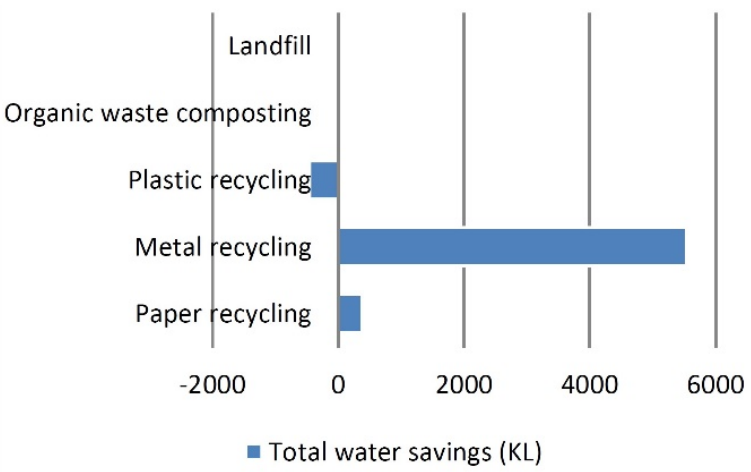

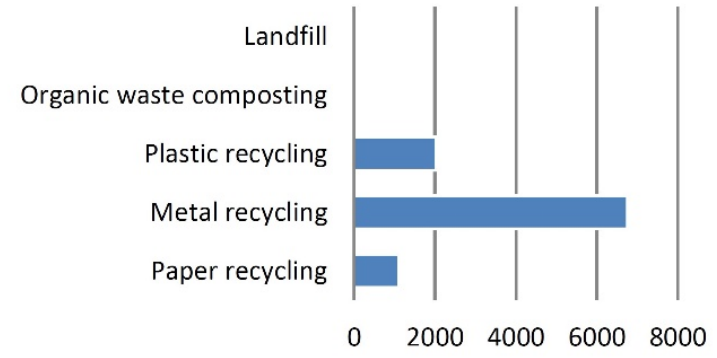

- Total energy susbsitited (GJHV)

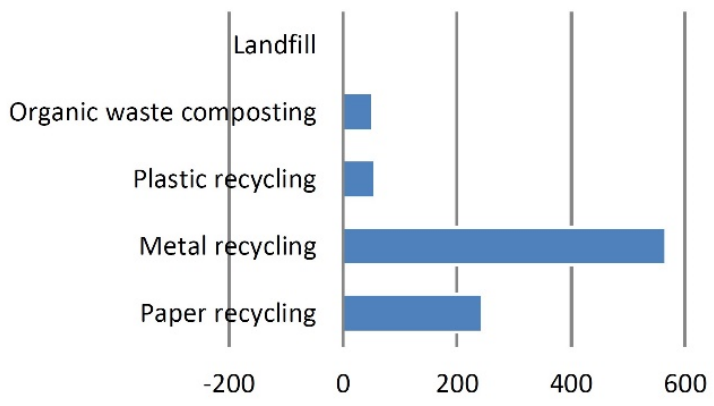

- Total GHG emissions reduction (tonnes $\mathrm{CO} 2 \mathrm{e}$ ) 
management systems have unequal environmental impacts. For example, organic-waste treatment does not have the same environmental impact as recycling waste, and recycling programmes have different environmental impacts. Moreover, as mentioned in the analysis of the highly ranked universities in the waste category of the UI green metric, to ensure a zero-waste campus, organic and inorganic waste should not be burnt to generate energy and should rather be prevented, recycled, or composted.

Waste management may impose a high cost on the university, but waste-management activities also have economic benefits. The prices of recyclable materials in the local market are based on supply and demand status. However, in recent years, average prices have been reported as follows: mixed plastic $280 \mathrm{JOD} /$ tonne, paper 35 $\mathrm{JOD} /$ tonne, cardboard $30 \mathrm{JOD} /$ tonne, aluminium waste $600 \mathrm{JOD} /$ tonne, and steel waste $65 \mathrm{JOD} /$ tonne (Jordan $\mathrm{GBC}, 2016$ ). Based on the market price for recyclables and the potential managed waste in AAU each year, revenues for selling recyclables can reach to more than 50,000 JOD/ year. The economic benefits of waste management also include associated energy, water, transportation, and GHG savings. While economics drives the waste-management system (Edwards and Pearce, 1978), local and global policy should promote the use of the best available techniques in the global waste-management system to guarantee that resource efficiency is maximised. Due to the complicated waste-management sector in Jordan, achieving zero waste at AAU would require separation partially on-campus site and primarily with private sector or NGO cooperation, with the public sector facilitating this collaboration.

\section{Conclusions}

This study is an investigation of solid-waste-management system performance potential for AAU in the context of environmental benefits, as measured against the UI green metric waste category indicators. The data produced in this study can be used by the Jordanian university administration to provide insights into potential solid-waste management strategies.

The study revealed that, at AAU, an average of 491 tonnes of mixed waste is produced each year, of which compostable waste accounts for around 104 tonnes, recyclables account for around 228 tonnes, and non-recyclables for around 159 tonnes. Using the ZWI to measure the performance of waste-management practices, the study found a score of 0.75 for non-recyclable paper and plastic prevention; paper, plastic, and metal recycling; and organic composting. Paper recycling has the greatest impact on virgin material substitution, and metal recycling has the highest potential for energy, water, and GHG savings.

Waste-management projects in Jordanian universities should apply both reduction and paper and metal recycling in phase 1 . Plastic recycling and composting should be applied in phase 2 . The reduction must target waxed cardboard in the form of plates, hot beverage cups, and food containers (non-recyclable paper), in addition to plastic types 3 and 6 in the form of clear food packaging, cups, and plates (non-recyclable plastic). Phase 1 recycling should target recyclable paper and cardboard, such as office and computer paper, as well as aluminium cans. Phase 2 recycling should target type 1 plastic in the form of water and soda bottles, as well as organic-waste treatment.

This study reveals that food and drink waste has a substantial impact at AAU. As a result, a pilot waste management project including the two described phases could be implemented in gathering areas, including restaurants and eateries on campus. The results should be measured and feedback taken into account when developing future improvements.

As different waste-management practices have different environmental impacts, the study recommends distributing the $\mathrm{UI}$ green metric waste indicators in accordance with environmental impact, giving more points to reduction and recycling. In addition, to ensure a zero-waste campus, it is recommended that the reduction of paper and plastic as a waste-management indicator should include both the waste-management system and the production system. Moreover, organic waste must be composed and inorganic waste must be prevented or recycled, not burned to generate energy.

\section{Acknowledgements}

This study is part of an ongoing funded project by Al-Ahliyya Amman University (AAU), Jordan to develop a roadmap for an environmentally sustainable university campus. The authors thank Al-Ahliyya Amman University staff for their cooperation. 


\section{References}

AAU (2019). Al-Ahliyya Amman University Environmental Sustainability Report 2017/2018. Al-Ahliyya Amman University, [online] available at: https://www.ammanu.edu.jo/ENglish/ pdf/Sustainability\%20Report.pdf [Accessed: 01/06/2020].

Alshuwaikhat, H and Abubakar, I. (2008). An integrated approach to achieving campus sustainability: Assessment of the current campus environmental management practices. Journal of cleaner production. 16, 1777-1785. https://doi. org/10.1016/j.jclepro.2007.12.002

Armijo de Vega, C. Benítez, S. Barreto, E. (2008). Solid waste characterization and recycling potential for a university campus. Waste Management, 28, pp 21-26. https://doi.org/10.1016/j. wasman.2008.03.022

ASTM International. (2016). ASTM D5231-92, Standard Test Method for Determination of the Composition of Unprocessed Municipal Solid Waste. West Conshohocken: PA.

Bailey, R. (2015). Solid waste management in the World's cities. UN-Habitat's Third Global Report on the State of Water and Sanitation in the World's Cities. Newcastle: EarthScan.

Britton, P.W. (1972). Improving Manual Solid Waste Separation Studies. Journal of the Sanitary Engineering Division, ASCE, Vol. 93, No. SA5, October, pp. 717-730

CallRecycle (California Department of Resources and Recovery). (2012). Glossary of Terms. [online] Available: https://www.calrecycle.ca.gov/LGCentral/Glossary/ [Accessed: 01/06/2020].

Chapman, P.F. and Roberts, F. (1983). Metal Re-sources and Energy. Boston: Butterworth, p.138 https://doi.org/10.1016/ B978-0-408-10801-0.50007-9

Connett, P. (2013) Zero Waste 2020: Sustainability in our hand. In Motivating Change: Sustainable Design and Behaviour in the Built Environment. London: Earthscan Publication.

Denison, RA. Ruston, J. (1990). Recycling and Incineration. Island Press, Washington, DC.

Edwards, R. and Pearce, D. (1978). The effect of prices on the recycling of waste materials. Resources Policy, 4(2), pp. 242-248. https://doi.org/10.1016/0301-4207(78)90002-8

EPA. (1996) Environmental Protection Agency: Municipal Waste Characterisation. Ireland: EPA

European Parliament and of the Council of the European Union, (2006). Directive 2006/12/EC on waste.[online]available at: http://eur-lex.europa.eu/legal-content/EN/TXT/?uri=CELEX\%3A32006L0012 [Accessed 01.05.2020]

European Parliament and of the Council of the European Union, (2008) Directive 2008/98/EC on waste and repealing certain Di- rectives. [online] available at: http://eur-lex.europa.eu/legal-content/EN/TXT/?uri=CELEX:32008L0098[Accessed 01.05.2020]

Eyinda, M. and Aganda, A. (2013) Municipal solid waste composition and characteristics relevant to the waste - to-energy disposal method for Nairobi city. Nairobi: Global Institute for Research \& Education.

Ghose, M. Dikshit, A. and Sharma, S. (2006). "A GIS based transportation model for solid waste disposal - A case study on Asansol municipality", Journal of Waste Management, 26 (11). https://doi.org/10.1016/j.wasman.2005.09.022

Glasgow Caledonian University, (2016) Waste Minimization \& Recycling Plan. [online] available at: https://www.gcu.ac.uk/ media/gcalwebv2/theuniversity/centresprojects/sustainability/reports/20160826\%20GCU\%20WMRP\%20V02\%20FINAL. pdf [Accessed 01.05.2020]

Japan International Cooperation Agency and Kokusai Kogyo. (2017) “Data collection survey on waste management in northern region accepting Syrian refugees in the Hashemite kingdom of Jordan, 2016," Japan International Cooperation Agency (JICA), Kokusai Kogyo Co, Ltd.

JGBC-Jordan Green Building council (2016) Your Guide to Waste Management in Jordan. [ebook] Jordan Green Building Council, the Hashemite Kingdom of Jordan. Available at: https://library.fes. de/pdf-files/bueros/amman/12729.pdf [Accessed 01.05.2020].

Klee, A. and Carruth, D. (1970) Sample Weights in Solid Waste Composition Studies, Journal of the Sanitary Engineering Division, ASCE, Vol. 96, No. SA4, Proc. Paper 4769, August, pp.945-954.

Marpman, A. (2011). Does Your Diversion Rate Really Reflect Your Recycling Efforts? [online] Available at: https://www.environmentalleader.com/2011/03/does-your-diversion-rate-really-reflect-your-recycling-efforts/ [Accessed: 01/06/2020].

Ministry of Environment. (2017) A National Green Growth Plan for Jordan. [ebook] Amman, Ministry of Environment. Available at: https://www.greengrowthknowledge.org/sites/default/files/A\%20National\%20Green\%20Growth\%20Plan\%20 for\%20Jordan.pdf [Accessed: 01.05.2020]

Ministry of Higher Education and Scientific Research, (2017) Institutions of higher education. [online] Available at: (http://www.mohe. gov.jo/ar/Pages/StateUniversities.aspx) [Accessed 01.05.2020].

Moqbel, S (2018). Solid Waste Management in Educational Institutions: The Case of the University of Jordan. Journal of Environmental Research, Engineering and Management, 74(2). https://doi.org/10.5755/j01.erem.74.2.21037

Mrayyan, B. and M. R. Hamdi. (2006) “Management approaches to integrated solid waste in industrialized zones in Jordan: $A$ 
case of Zarqa City." Waste Management 26(2), pp. (195-205). https://doi.org/10.1016/j.wasman.2005.06.008

Parvez, N. and Agrawal, A. (2019) Assessment of sustainable development in technical higher education institutes of India. Journal of cleaner production. 214, 975-994. https://doi. org/10.1016/j.jclepro.2018.12.305

Price, J.L. \& Joseph, J.B. (2000) Demand management-a basis for waste policy: applicability of the WH in terms of achieving sustainable waste management. Sustainable Development, 8(2), pp:96-105. https://doi.org/10.1002/(SICl)10991719(200005)8:2<96::AID-SD133>3.0.CO;2-J

Schall, J. (1992) Does the Solid Waste Management Hierarchy Make Sense? A Technical, Economic and Environmental Justification for the Priority of Source Reduction and Recycling. Working paper \#1. Program on Solid Waste Policy, Yale University.

SENES. (1999) Recommended Waste Characterization Methodology for Direct Waste Analysis Studies in Canada. Canada, Ontario: SENES Consultants Limited.

Smyth, D. P. Fredeen, A. L. \& Booth, A. L. (2010) Reducing solid waste in higher education: The first step towards "greening" a university campus. Resources, Conservation and Recycling, 54(11), pp: 1007-1016. https://doi.org/10.1016/j.resconrec.2010.02.008

Starovoytova, D. (2018) Solid Waste Management at University Campus (Part 5/10): Characterization and Quantification of Waste, and Relevance of the Waste Hierarchy in its Management. Journal of Environment and Earth Science, ISSN 22243216 (paper), Vol.8, No.8.

Stocker, T. IPCC. (2013) Technical Summary. In Climate Change 2013: The Physical Science Basis. Contribution of Working Group I to the Fifth Assessment Report of the Intergovernmental Panel on Climate Change. IPCC: Geneva, Switzerland, pp. 159-254.

UC Davis, (2009) Solid waste management policy, LEED EBOM v2009. [online] available at:https://sustainability.ucdavis.edu/ local_resources/docs/zero_waste/solid_waste_management_policy.pdf [Accessed 01.05.2020]

UI Green Metric. (2019) Methodology. [online] Available at: http:// greenmetric.ui.ac.id/methodology-new/ [Accessed 01.05.2020].

UI Green Metric. (2019) Overall rankings 2019, [online]Available at: http://greenmetric.ui.ac.id/overall-rankings-2019/ [Accessed 01.05.2020].
UNEP-United Nations Environment Programme. (2015) Global Waste Management Outlook. [ebook] United Nations Environment Programme. Available at:https://wedocs.unep.org/bitstream/handle/20.500.11822/9672/-Global_Waste_Management_Outlook-2015Global_Waste_Management_Outlook.pdf pdf? sequence=3\&amp\%3BisAllowed $=$ [Accessed 01.05.2020].

UNDP-United Nations Development Programme. (2015) Human development report 2015 - Work for human development Mozambique. [online] Available at: http://hdr.undp.org/en/ countries/profiles/MOZ [Accessed: 01/06/2020].

Wageningen UR University \& Research centre, (2018) Wageningen UR Waste policy $\&$ implementation. [online] available at: https://www.wur.nl/upload_mm/d/6/0/4bfd080d-8c83-4df6990e-d6e917993953_20140325_Afvalbeleid_Wageningen_ UR_versie1_engels_intranet.pdf [Accessed 01.05.2020].

Wagner, J. and Bilitewski, B. (2009) "The temporary storage of municipal solid waste - Recommendations for a safe operation of interim storage facilities", Waste management, 29. https:// doi.org/10.1016/j.wasman.2008.11.018

Yu, C. and Maclaren, V. (1995) "A comparison of two waste stream quantification and characterization Methodologies”. Waste Management and Research s, 13. https://doi.org/10.1016/S0734242X(95)90084-5

Zaman, A.U. (2014) Measuring waste management performance using the 'Zero Waste Index': the case of Adelaide, Australia. Journal of Cleaner Production, 66, pp: 407- 419. https:// doi.org/10.1016/j.jclepro.2013.10.032

Zaman, A.U., Lehmann, S. (2013) The zero waste index: a performance measurement tool for waste management systems in a 'zero waste city'. Journal of cleaner production, 50, pp 123132. https://doi.org/10.1016/j.jclepro.2012.11.041

Zaman, A. U., Shahidul, M., \& Swapan, H. (2016) Resources, Conservation and Recycling Performance evaluation and benchmarking of global waste management systems. "Resources, Conservation \& Recycling," 114, 32-41. https://doi. org/10.1016/j.resconrec.2016.06.020

ZWIA, (2009). ZW Definition, Zero Waste International Alliance. [online] Available at http://zwia.org/standards/zw-definition/ [Accessed: 01.05.2020]. 